\title{
Community Film Making and innovative direction of rural art (An ethnographic study on a Sri Lankan community film 'Walapane Satana')
}

\author{
Aruna Lokuliyana, Ileka Ruwanpathirana \\ Department of Mass Communication, University of Kelaniya, Sri Lanka. \\ lokuliyana@kln.ac.lk, ilekahansanie@gmail.com
}

\begin{abstract}
'Community film' is an attractive new term that has been emerged over the past few years. Though Sri Lankans are familiar with 'Community radio', the phrase 'Community film' is still a novel idea. But, it has been recognized by the world that community filmmaking is a broad concept that can be understood and produced in different ways, such as participatory community filmmaking and non-participatory community filmmaking. This study focuses on 'participatory community filmmaking' and tries to understand how it works, why it is made, what the benefits are, and how we can use it as a tool to achieve something positive. Under the qualitative research approach, an ethnographic study was performed. Films have been classified under various criteria, and it helps to understand what type of film it is. Primary and secondary data were collected. Preliminary data was collected through participatory observation and interview methods. Since the film, 'Walapane Satana' was the only film found from Sri Lanka and easily fit into the criteria to call it a community film, it was used for the study. The research revealed a solid sociocultural background behind the making of this film. This particular community film has influenced the development of the place and individuals of this village in many ways. Almost all the villagers have participated in this film to attend and make, teach, learn, present, promote, judge, support, and span many artistic disciplines. Most importantly, some people have given up their lifelong bad habits to become a part of this film, and at the end of the film, they have entirely dumped those habits and have started effectively leading their lives. Furthermore, being a part of this film has added value to their lives, and it has empowered and educated them to become worthy citizens. These findings led the researcher to conclude the study with a strong opinion on community filmmaking as a powerful driver for social change.
\end{abstract}

Keywords: Community film; Participatory community filmmaking; Communication; Ethnographic study; Sri Lanka 


\section{Introduction}

Mass media refers to the diverse array of media technologies. It comes in different shapes and sizes like print media, electronic media, digital media, new media etc. These classifications have been created based on the technology where this communication takes place.

Community media is a practice and approach introduced to challenge the dominant use of media and empower communities to achieve development goals. As UNESCO defines it, "community media, whether broadcast or online, are crucial to ensuring media pluralism and freedom of expression, and are an indicator of a healthy democratic society. As an alternative medium to public and commercial media and social media, they were characterized by their accountability to and participation of the communities they serve. In addition, they have a greater focus on local issues of concern and facilitate public platforms for debate and discussion". (UNESCO, n.d.) Furthermore, UNESCO emphasizes that they advocate strongly for community media independence and run for and by the community.

Community Radio is the first attempt to establish community media worldwide, and Even Sri Lankans are familiar with the concept of Community radio. The setting up of the Rajarata Sevaya in 1979 marked the beginning of the decentralization of radio in Sri Lanka. Since then, the Rajarata Sevaya has grown to be one of the most popular provincial services. (Center for policy alternatives, n.d.) Later on, more provincial radio stations were established like Ruhunu Sevaya in 1980, Kadurata Sevaya in 1983 etc. And setting the Mahaweli radio in 1981 was the first attempt at starting community radio in Sri Lanka. But there is a question that, are these radio stations truly serves the community media concept?

It was questioned for the first time by Tilak Jayaratne and Sarath Kellapotha, mentioning that "Community Radio in Sri Lanka is a misnomer, as the stations are not owned, managed and run by the community." (Jayaratne \& Kellapotha, n.d.) 
"Community radio in Sri Lanka not truly community radio, in that the stations are administrated and run by the government and not the community." (Center for policy alternatives, n.d.) This report says that the government also exerts control over the content to avoid criticism of the government and ensure that this medium isn't misused by any political party to set its agendas. However, when it comes to the process of community media, Sri Lankan community radio doesn't do justice to the original idea. Simply, true independent community media has never been allowed in Sri Lanka. Thenceforth it has been questioned by some other people as well.

Besides community radio, there are some other community media practices as well. Community newspaper, community video and community film are some of those community media practices identified within this discipline. For example, we can consider an award-winning community weekly newspaper called 'The Budget'. It is circulated throughout Holmes country and neighbouring communities. This newspaper also publishes a national edition commonly referred to as the Amish newspaper. ("The Budget," n.d.) Another best example is a film called 'Supermen of Malegaon (2008). This is a documentary film directed by Faiza Ahmad Khan, who lives in the small town 'Malegaon' in the Nasik district of Maharashtra, India. He is a guy with no prior training and experience who decided to make films and succeeded. Today they have their film industry known as Mollywood, or occasionally, Malliwood. (Kumar, 2017) Community filmmaking is the newest and most bold practice of community media since it has all the magic of the visual medium. So it's better to have an idea about community filmmaking and where it is coming from?

'Community filmmaking originates in the community arts and media movement of the 1960s, which aimed to challenge mainstream arts and media values and production systems by giving a voice to every citizen to represent and cater better for the needs of all parts of society. Whatever their position or background, and to elicit social change and support political contestations' (Berrigan \& Unesco, 1977; Carpentier \& Scifo, 2010; Malik, Chapain, \& Comunian, 2017; McKay, 2010). 
This statement can be considered a definition of community film or community filmmaking since there is no bold definition for community filmmaking. This statement can be tested by asking few questions on community filmmaking to understand the concept correctly and accept this as a definition for community filmmaking.

In community filmmaking,
i. Who holds the camera?
ii. What's the story?
iii. Why this story?
iv. Who is in front of the camera?
v. What's inside the frame, and what's outside?
vi. How was the film assembled and edited?
vii. Who owns the film?
viii. What is the intention of making the film?

'Community is the only answer for all the questions. And the idea, which was started by Berrigan, Carpentier, Scifo, McKay, Malic, Chaplain and Community, is a compressed idea that answers the questions mentioned above. Since their statement fits with the norms of community media (the community should run it, it should be done for the community, and the community should own it), let's consider it as a definition of community filmmaking.

When it comes to community filmmaking practice in Sri Lanka, it's entirely a novel idea. That doesn't mean that professional filmmakers make all the Sri Lankan films, and there were no alternatives. There are films, short films, documentaries films done by armature artists. But those videos or films can't be counted as community films or community videos since they don't meet with needs and objectives of community filmmaking. When we consider the academic and research field, community filmmaking is not as popular as community radio or community newspapers. It's visible that less scholarly attention has been given in to this field. We think it's because we (Sri Lankans) never had the experience of making or watching a community film in the real sense of the word. That's why the film 'Walapane Satana' 
made by a 70 years old man, Munidasa Punchhewa, with the help of 150 villagers, becomes a landmark of the community filmmaking practice in Sri Lanka. This film made history by claiming the first film of this kind.

Walapane is a village in Sri Lanka located in Nuwara-Eliya district, central province. It was called Wathumulla in the past, and it is a hill country area with lots of green mountains. 'Walapane Satana' (The Freedom Struggle in Walapane) is about villagers who lived in Walapane 200 years ago. This village is one of the villages which says a lot about the history of Sri Lanka. The freedom struggle of 1817-1818, also known as the 1818 Uva-Wellassa uprising, was the third of the Kandyan wars against British colonial forces. It happened in areas of Uva-Wellassa, and Walapane was one of the prominent locations of this struggle. Freedom fighters (So-called rebellions according to the British colonial point of view) used this village as a hideout, and 200 years ago, it was a battlefield. This film reveals how villagers in Walapane got ready to be a part of this freedom struggle.

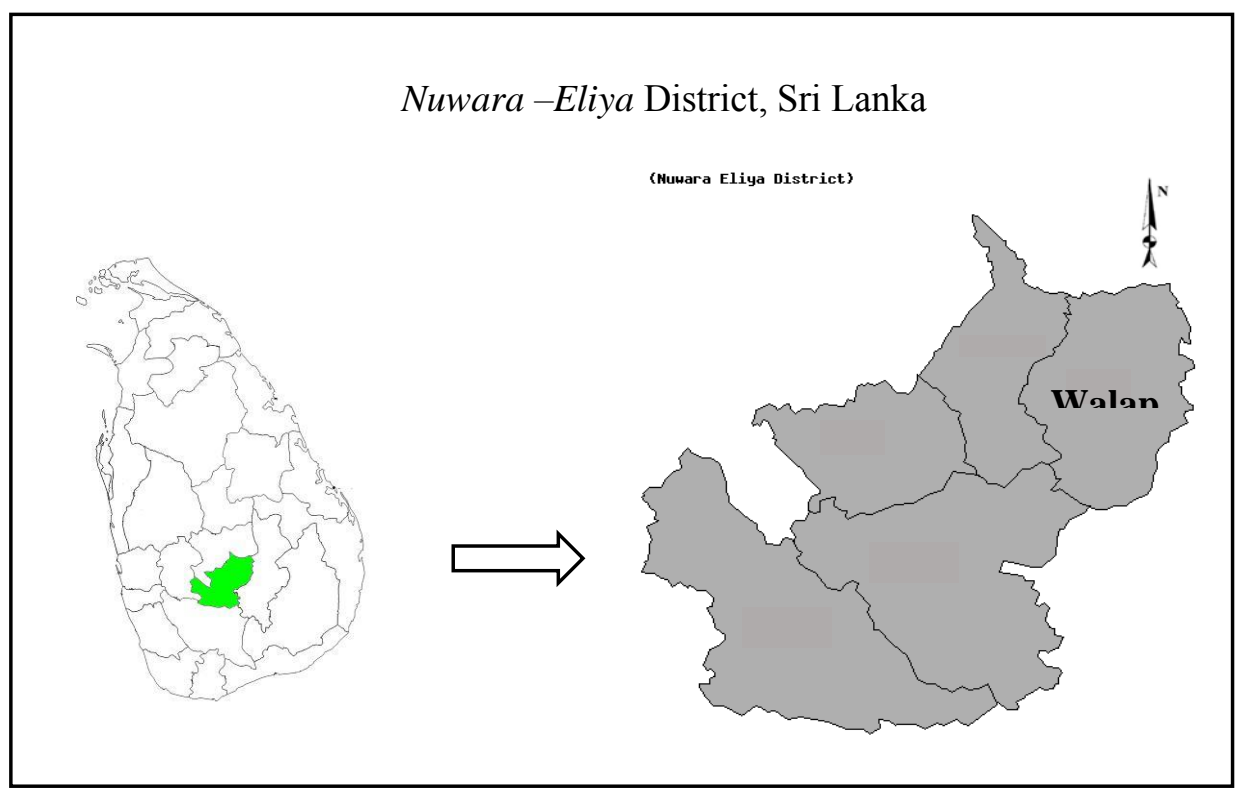

Source-Survey Department of Sri Lanka ( http://www.it.survey.gov.lk/nsdi/gis/index_grid_50k.php)

Basic Information about the film 'Walapane Satana' 
- Story/Director/Producer - Munidasa Punchihewa

- DOP, Editor - Ashan Punchihewa

- Art Director - Sarath Ananda

- Stunt - Chamindalal

- Audio Recoding - Buddika Priyashantha

- Narrator - Kalum Bandara

- Duration $\quad-1$ hour and 55 seconds

- Production year - 2018

This research was carried out to understand community filmmaking' by studying the film 'Walapane Satana'.

\section{Research Problem}

How community films are originated, made and how it affects the particular community?

\section{Objective}

The main objective of this research is to understand how community filmmaking works, why it is made, what the benefits are, and how we can use it as a tool to achieve something positive.

\section{Literature Review}

As it's popped up from the literature, there are not many academic works related to community filmmaking. However, there are researches and studies related to community media practices all over the world. However, mainly there are no inquiries in the Sri Lankan context about the field of community filmmaking. Therefore, the researchers tried to collect information by referring to studies carried out by foreign countries and state some essential ideas central to the discipline of community filmmaking.

Malic, Chapain and Comunian have explained the form of community filmmaking. "Community filmmaking could take the form of individual and group filmmaking and be part of the professional or non-professional realm. As such, there was 
recognition that community filmmaking could take various forms depending on the degree of involvement of communities in the filming process and the ethos of the filmmaker(s) involved."(Malik, Chapain, \& Comunian, 2014)

The literature review found that researchers in different perspectives have studied community filmmaking as a field of inquiry. Malik and the team have researched how cultural diversity is understood and practised within community filmmaking today. They have used the UK film sector to adopt inclusive film practices and approaches that support cultural diversity. They have proved by their research that film is perceived to be a powerful space for community participation and engagement and as a tool for social, political and artistic expression. Film functions as a medium that creates and maintains shared values, contributes to intense feelings of cultural and group identity and generates modes of belonging. "For our participants, the visual medium of the film also offers opportunities and lends itself well to working across a range of other creative disciplines and spaces (dance, music, animation and social media, for example)." (Malik et al., 2014)

One crucial fact that can be brought out from the literature is that some seminal terms have been used to describe the films and videos made by non-professionals. As a result, people get confused with the words and it is needed to be clear out the difference or similarity between the terms like community video and participatory video.

Gareth Bennett, Director of Programs at Insight Share (Insight Share is a community development organization based in Oxford, United Kingdom) and, works globally with 15 years' experience combining media technology, with participatory approaches and community engagement for a locally-led change) has explained his opinion on the differences between community video and participatory video in a comprehensive way. "As I see it: Community video - filmmaking by a community. Participatory video -filmmaking by a community, as a means to achieve positive social change." (Community communication, 2015) In his interpretation, community 
video refers to processes that engage a community/group in video production as an end in itself. By contrast, the participatory video uses video to achieve the desired social change outcomes of the community involved. It sets out to harness video to address issues and circumstances that might benefit from being aired, shared or documented for the future. Often the participatory video is deployed as a medium for establishing communication channels between groups that otherwise may not engage in direct dialogue.

It's confusing to differentiate between community video and participatory video since each practice's core looks the same. Some practitioners have used the word 'participatory' with the 'community video' just to emphasize that there are different types of community films. "On one level, there is participatory community filmmaking, where the filmmaking process is wholly managed and undertaken by the community involved. At the other end of the spectrum, there is non-participatory community filmmaking, where community filmmakers who might film community issues but do not involve communities in participatory ways." (Malik et al., 2017) So it is understandable that these seminal terms confuse researchers. Though Gareth Benest has given definitions to each word community video and participatory video, even he has admitted that he wanted to emphasize how different participatory video is. "This is by no means meant as a criticism of community video, just an attempt to articulate how different participatory video is." (Community communication, 2015) Therefore to understand this researcher thought of reviewing literature related to participatory video as well. The author of the book 'Handbook of Participatory Video' and others have explained this by quoting a statement by The Walton Hall Statement on Participatory Video in Research (PV-NET). "Participatory video can be understood as a collaborative approach to working with a group or community in shaping and creating their film, to open spaces for learning and communication and to enable positive change and transformation' This definition emphasizes an open, experimental approach to participatory video." (Milne, Mitchell, \& De Lange, 2012; Roberts \& Lunch, 2015) 
Milne, Mitchell and De Lange explain a little further, focusing on the qualities of participatory video. Here they have quoted an idea of Shaw and Robertson. "Because of the focus on capacity building amongst marginalized people, participatory video can be understood in terms of a process wherein people themselves understand the video project methodology and process and control the content of the video productions. In this sense, the main objective of participatory video communication is not to produce media materials per se, but to use a process of media production to empower people with the confidence, skills and information they need to tackle their issues.' (Shaw \& Robertson, 1997) Within this definition, there are two key elements linked to empowerment, which are worth noting: (i) participants taking control of the production process, and (ii) participants tackling their issues." (Milne et al., 2012)

Lara Damiani, a blogger and a filmmaker, wraps up her idea on participatory video by mentioning, "People talk about Participatory Video, which is something else I'm passionate about, but I think it's also about providing opportunities for participation (and new skills) with the people I work with in the field. Giving them the chance to get behind the camera or work with audio." (Damiani, 2017)

However, whether it is community video or participatory video, both play a significant role as alternative media and community communications tools. Orbach, Rain and Contreras have proven it by their researches. They have focused on how Mapuche Indigenous communities use video and digital filmmaking to reflect on and communicate knowledge in southern Chile collectively. They have suggested that video can be a powerful tool for self-representative knowledge-sharing by Indigenous communities. "Participatory video (PV) came onto the development scene as a way to put audiovisual tools into the hands of local people and communities. PV harnesses the accessibility and immediacy of the video camera to bring members of a group or community together to identify issues, share experiences, and discuss solutions. It is considered a path to individual and community empowerment, both because it builds capacity to manipulate technology and control a process of creation, and because it stimulates collective analysis, problem-solving, and action." (Orbach, Rain, \& Contreras, 2015) 
Even Damiani's statement on participatory filmmaking supports Orbach's idea. Damiani says that filmmaking and community development is a great partnership. "We believe engaging communities in the filmmaking process is critical. We're not the type of filmmakers who walk in, set up cameras, shoot and walk out. We prefer to engage with communities and assist, where we can, with community development as part of our social documentary filmmaking process." (Damiani, 2015) Damiani believes that letting people engage with the filmmaking process helps develop news skills within them, and it's a powerful tool for social change where visual stories can demonstrate impact to audiences worldwide. Their participation and involvement at a community level can engage, stimulate and stimulate and educate people.

After reviewing the most relevant literature on community filmmaking in different approaches, finally, the researcher was able to wrap up the argument by understanding that film or video made by communities, for themselves to educate and empower them, can be considered community film or video. However, since this is the idea of foreign studies, it's better to cross-check it with the Sri Lankan practice of community filmmaking.

\section{Research Methodology}

Under the qualitative research approach ethnographic study was performed for this research. Since this research aims to understand the community filmmaking concept and how it originated and affected the community, we needed a methodology that helps to interact with a study's participants in their real-life environment. To fully understand as much as possible about the particular community and to deliver a detailed and faithful representation of the behaviour of people, attitudes and emotions, we decided to perform an ethnographic study.

Type of data - Primary and secondary data were collected. Since the film, 'Walapane Satana' was the only film found from Sri Lanka and easily fit into the criteria to call it a community film, it was used for the study. 
Data Collecting - Primary data were collected by interviewing the participants of this film and by doing participatory observation. Secondary data were collected from research papers, reports, blog articles, books and newspaper articles.

Sample - Interviewees were selected using a random sampling technique. But the researchers were conscious of choosing the model that represents different social classes and ranks to understand how this film made a platform for these people to interact with each other.

\section{Data Analysis}

\section{The director/producer - Munidasa Punchihewa}

"I have never learned anything about film or filmmaking. I was born in Dewundara (The southern part of Sri Lanka). I'm the third child of my family, where there were ten children. Later we moved to Lunugala (Village in Uwa Province of Sri Lanka). I was a terrible student and didn't complete my studies properly. I stop going to school after completing grade 5. But thanks to the principal, I could find a job and survive because he gave me the school leaving certificate certifying that I passed the $8^{\text {th }}$ grade. Thenceforth I started working as a driver. While working in the Ratmalana area (Town in Western Province of Sri Lanka)as a CTB (Ceylon Transport Board) driver, I went to my village on holiday. On a day like that, I went to see the Dunhida waterfall with my friends. There was a kind of meeting and we also just joined with those people without knowing who they were. That was the year 1971. I was arrested by Modara police, telling me that I was a JVP rebellion. (Janatha Vimukthi Peramuna, also known as JVP, is a communist and Marxist-Leninist party and Political movement in Sri Lanka) I was prisoned for two years. After coming out of the prison, I was transferred to Nuwara-Eliya and later to Walapane. That's where I met my wife and settled down in this beautiful village called Walapane." (Punchihewa, 2018; Samarawickrama, 2019) 
Though Munidasa Punchihewa was a bus driver, he has a born talent for artistic works. He is an artist by himself. He is good at painting, sculpting, etc. He happens to be the first one who built a 'Wesak thorana' (A Part of Buddhist ritualistic ceremony) in Walapane village. It was the year 1978, and until then, villagers have never seen a 'Wesak thoran'. What he got in return for doing this was a punishment transfer. He was disappointed with the people and job, and he left the job and went to gemming. "My cousin brother K.P Sunil Shantha got a gem, and he wanted to make a film. I went to help him as a driver, and my duty was to take the cast to the set and drive them back to the lodge. 'Binari saha Sudu Bande' (1984) was the name of that movie. Lionel Silva was the art director of this film, and I used to give side supports to him. Suddenly he decided to leave the film and join another big film. He wanted me to take over and keep working in his position. I just did work in the art department and didn't take it seriously. After the movie release, I was shocked to see my name on the screen under the title of assistant art director. That's my only experience in the film industry." (Punchihewa, 2018; Samarawickrama, 2019)

After that, he has come back to the village, and a person he met in prison has offered him a job as his driver. Munidasa has gladly accepted the position, has worked as a driver for 12 years, and has retired from his career. But the passion he had for art was still there with him, and he started using his time after retirement to make stage dramas, Tele-films, and other social works. He has directed four-stage dramas, one Tele-film and one film including 'Walapne Satana'. Though he was an outsider, villagers have accepted him as their own native and Munidasa Punchihewa became an opinion leader of this village. While he was reading about the history of this village, he has found out its contribution to the 1818 freedom struggle. So then, with great respect for their ancestors, he has thought of making a film, and that's how the film 'Walapane Satana' happened to be stated.

\section{The intention of making the film}


As Munidasa mentioned, his pure intention was to do something with the collaboration of all the villagers. Though he is an outsider, he has highly attached to this village Walapane and the people. Therefore, he has decided to make a film to empower the villagers and serve the township where he lives.

\section{Film Making Process}

As Munidasa Punchihewa explained, it wasn't an easy task. 'I was 70 years old, and I had no idea from where should I start. But this was something I wanted to do for a very long time. (Punchihewa, 2018)

- Script - There was no proper script for this. Munidasa has just drafted all the scenes daily, and every scene has been briefed to the cast daily after they come to the set. 'I don't know how to write a film script. But I know how the story should be told. I just follow my instinct and put together the scenes." (Punchihewa, 2018) Researchers observed the audience's reaction in different social groups, and it was evident that the audience was very much interested in the film. This film contains humour, action, sorrow, arrogance and the list goes on. The audience showed emotions related to each mood. They laughed. They got excited. That's not to say that the film was devoid of any boring scenes. Since it runs for two hours and sixteen minutes, there are some sequences. But the audience didn't dump it because the very next scene again picked them up. Therefore we can say that the director has shown some skills in filmmaking by creating the storyline.

- Selecting the crew and cast - This is one of the sections where the researcher noticed the value of making this type of film. As we mentioned earlier, Walapane is a tiny village away from Colombo. The lifestyle of this village is unique since they have to manage day-to-day needs within the community. The majority of them are farmers. Higher ranks of the social groups serve the government as teachers, policemen, Provincial Council Members etc. The research revealed that there was no suitable platform for these people to interact with each other. And this film has created a unique space for all of them to get to know each other. 
Within the cast and crew of this film, there are Provincial Council Members, Pradeshiya Sabha Members, Farmers, Bus Drivers, Three-wheel Drivers, School teachers, Children (Different age groups), Housewives, Unemployed boys, Buddhist monks, Dopers/ inebriates, Thugs, Thieves, Businessmen, Technicians, Smiths, and Retired Army Soldiers etc. However, the most notable thing revealed by the research is that marginalized people of this particular village mentioned that they got the attention, recognition, and acceptance from the society they belong to after acting in this film.

- Directing the film - The techniques which the director of this film has used are impressive. Although, according to his basic knowledge, he has no idea about the theories and practices in acting and directing, such as 'Method acting or role play', he had done all of these things practically to make the villagers act in the film. "I knew that the villagers are not used to act or deliver dialogues in front of a camera. But all of them were so excited to be a part of this film. They did watch films and wanted to become stars. And I knew what they are good at. Some are good at climbing trees, some are good at fighting and arguing, some are good at drinking alcohol, and others are good at cheating. I matched their personal qualities with the characters of this film and offered suitable characters for each of them. As an example, a husband and a wife who sell fish in the market always end the day fighting with each other. All the villagers are used to seeing this, and I did ask them to do the same thing in the film, and they did a great job. That's how I made them act." (Punchihewa, 2018) Not only that, Munidasa has ordered toddlers to stay away from alcohol only if they want to act in the film. So, people who can't live without drinking alcohol have started practising living their lives without drinking alcohol. By analyzing the techniques of this director, we can say that he hasn't played just the role of a director but the role of a teacher, leader, and psychologist.

- Art Direction/ Costume \& Makeup - Munidasa and his team have made all the costumes, props and film sets. As he mentioned, Preparing costumes, props and film sets was the biggest challenge since this storey happened 200 years back. These people didn't have money to buy chemicals, ingredients, and other stuff to 
age the costumes or build film sets. However, they have managed to recreate everything as much as possible using all the resources they had.

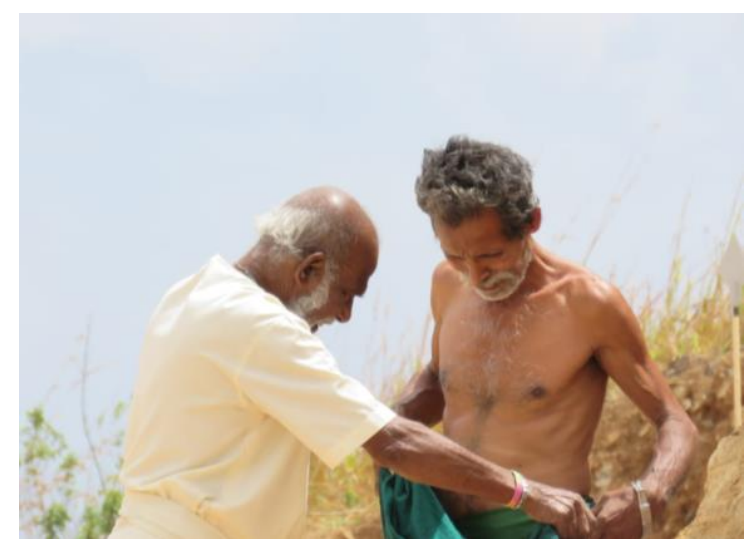

Picture 01- The director is dressing up an actor

Source - Primary Data (A working still of 'Walapane Satana' film)

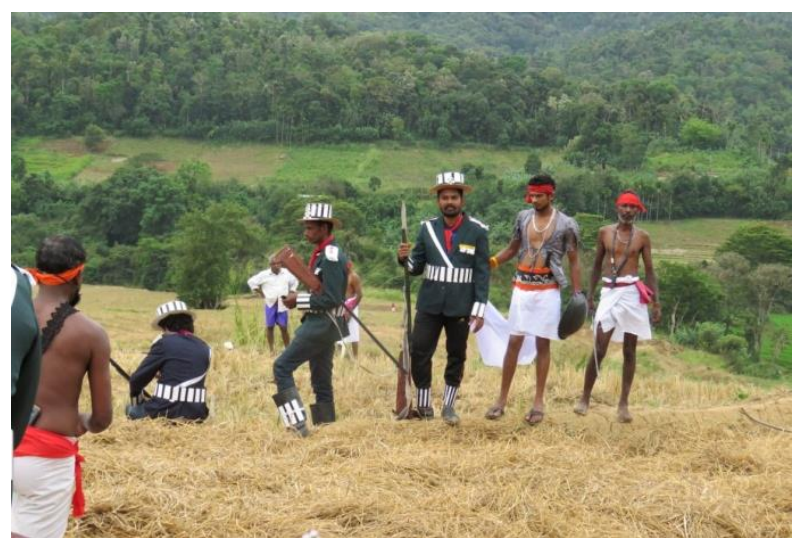

Picture 02- Dressed up actors

Source - Primary Data (A working still of 'Walapane Satana' film)

Production Management - Munidasa mentioned that the entire production did cost 30,000 Sri Lankan rupees only. Finding 30,000 (average 200 US dollars) rupees also was a difficult task, and they have shot the film from time to time depending on the money they have. They have no idea about budgeting and production management. Munidasa Punchihewa's pension was the only source of funds. When it comes to food and transportation, they have been provided breakfast, lunch and sometimes dinner to the film set by the villagers who live closer to the set. Three-wheel drivers have 
given rides voluntarily. And this piece of work has become their production. (Punchihewa et al., 2018) (Sega, Ananda, \& Chamindalal, 2018)

- Technology (Camera Equipment/ light/ Sound/ Edit) - Next challenge was to overcome the technical issue. The director of this film Munidasa Punchihewa and the cinematographer Ashan Punchihewa (Munidas's youngest son), have managed to film the entire movie without tripods, monopods, grips, tracks and dollies. "A few years back, I sent Ashan for a technical course, and he knew how to operate a simple camera. I bought a very cheap ordinary camera for him. Even he didn't know about cinematography, and he just helped me by shooting this film without any other technical equipment." (Punchihewa, 2018) Ashan has shot the entire film using handheld camera techniques. Nikon P600 was the camera he used to shoot the movie.

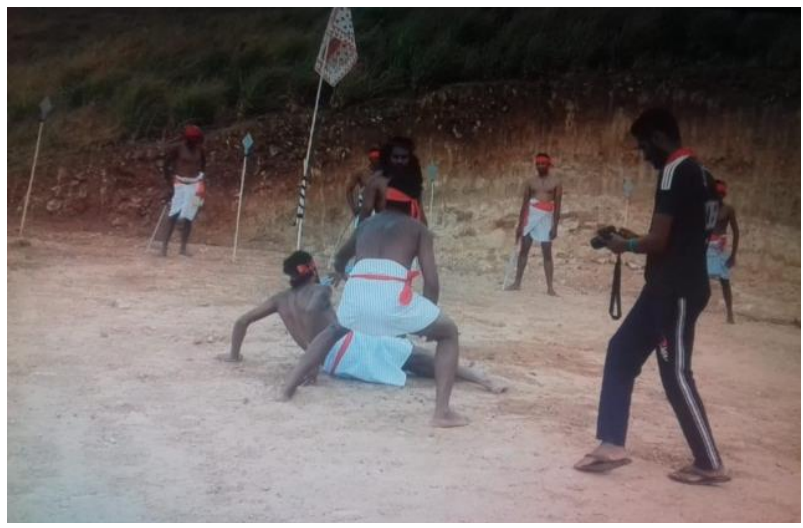

Picture 03-Ashan Shooting the film

Source - Primary Data (A working still of 'Walapane Satana' film)

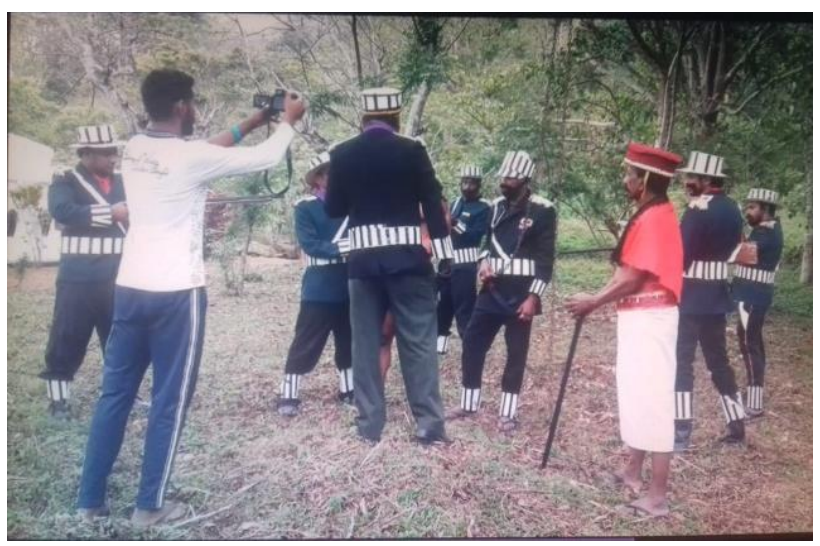

Picture 04-Ashan Shooting the film

Source - Primary Data (A working still of 'Walapane Satana' film) 
Sometimes the audience can notice the camera jerks. It's because they have no idea about the camera techniques, lighting and sound engineering of a film. They have shot this using natural light. Because of that, the audience can notice disturbances while watching the movie. Most of the scenes of this film are outdoor scenes like near a waterfall or in a forest. Since they haven't used a proper sound recording method, the audience can't hear the dialogues of few scenes. But the most important fact is, though there are many technical errors, some shots in this film are highly cinematic.

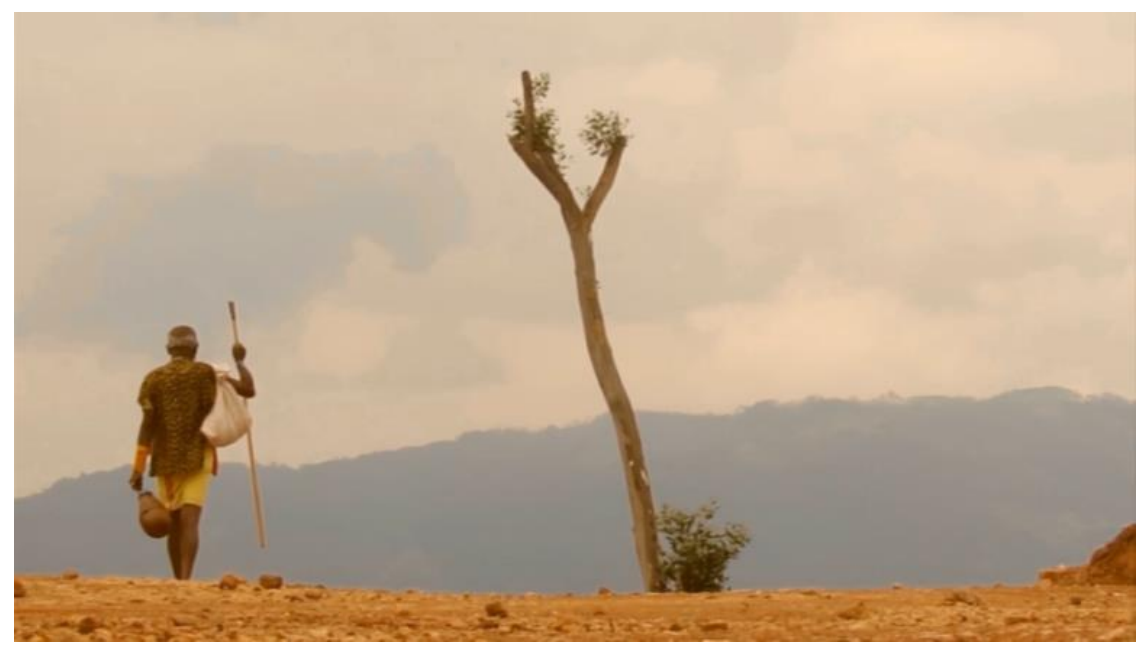

Picture 05 - A shot from 'Walapane Satana' film

Source - Primary Data

- Stunts - People in Walapane fought for the country in 1818, and, in this movie, there have to be many stunts represent it. But there was no professional to tell them this is how actions are working in films. Retired army soldiers were the only hope for them. So they have come forward to do stunt actions in this film. Unfortunately, one person has fallen from a high place during the shoot and got injured. Since this happened during the shoot, it has been recorded and can be seen in the film. 


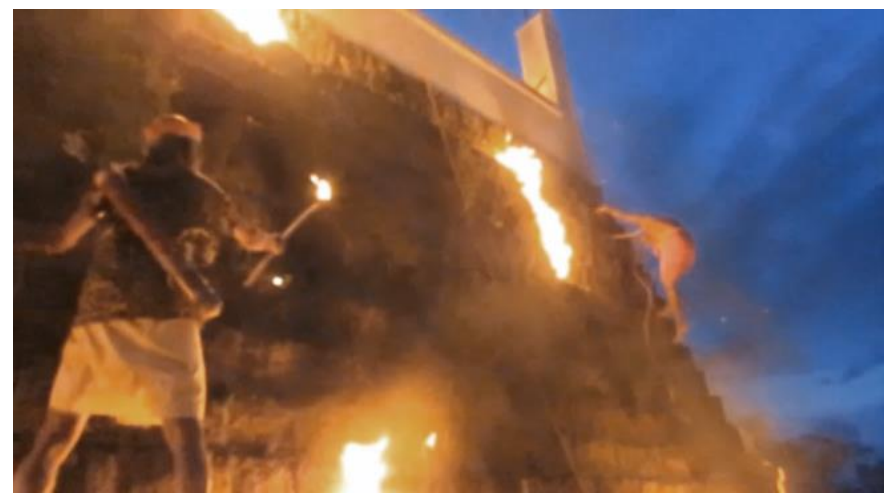

Picture 06 - One actor is falling down from the wall

Source - Primary Data (A shot from 'Walapane Satana' film

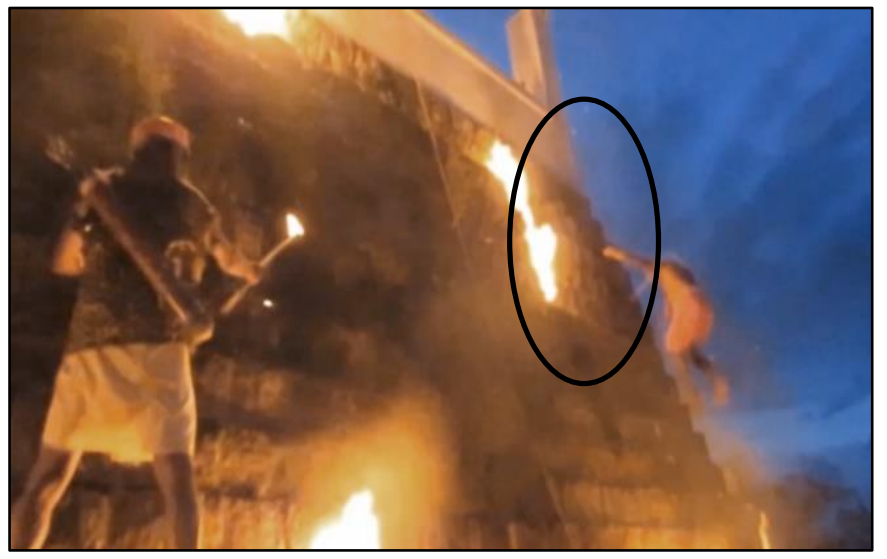

Picture 07 - One actor is falling down from the wall

Source - Primary Data (A shot from 'Walapane Satana' film

And the most inspirational fact is that he has come to the set a few days later to support his fellow crew members after receiving treatments.

- $\quad$ Film screening and publicity -

- The first film screening was held on October 24 2018, at the main hall of Sri Sumangala national school, Nildandahinna, Walapane. Later there was a special film screening at the Department of the Mass Communication University of Kelaniya, and thenceforth this film was screened several times in Walapane. Researchers observed three film screenings by attending each event, and it was noticed that they used the main hall of schools as a film hall. They did carry the technical equipment like projector, cables, laptop and screened the film. People had to buy tickets to watch the movies, and it was free of charge for school children. The cost of the ticket was fifty 
Sri Lankan rupees. The most important fact is they donated the income to each school where they screened the film. When it comes to the publicity, they have used posters drawn by themself and have hung them on trees.

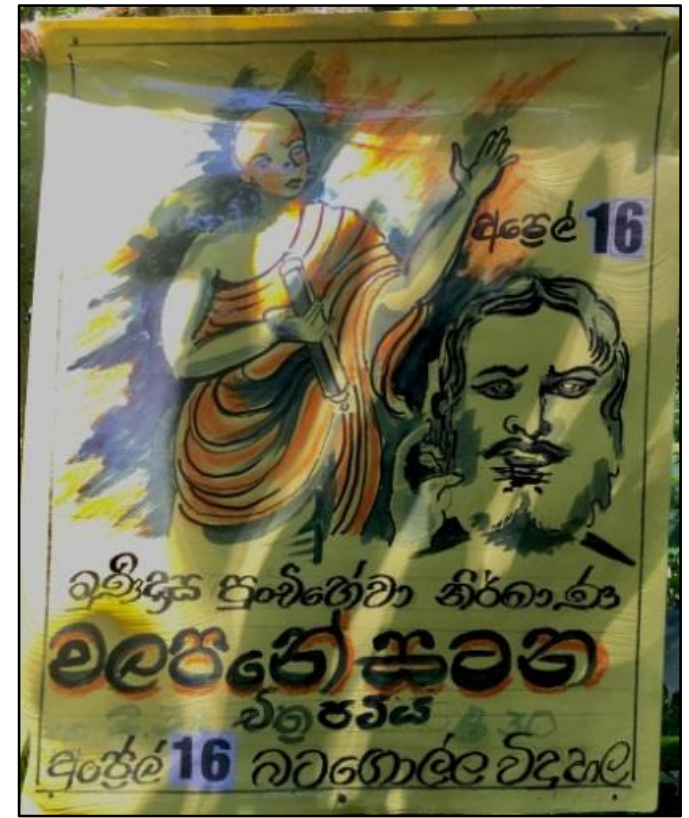

Picture 08 - A film poster of 'Walapane Satana'

Source - Primary Data

In addition, they used a publicity truck, and the researcher could experience how this truck went here and thereby announcing the date, time and venue of the film screening.

\section{Findings and Conclusion}

It was proved from the research findings that this film was entirely made by villagers who have no idea what filmmaking is. However, they have gotten together to make a film, build willpower, engage with each other, appreciate each other, and represent their culture and beliefs. Based on the findings, we can clearly state that 'Walapane Satana' is a community film by a real sense of the word. Some can identify it as a 
participatory community film where the filmmaking process is wholly managed and undertaken by the community involved.

And the latter part revealed that the origin of such a film is based on a solid sociocultural background. These villagers are driven by decisive historical factors related to the early Kandyan Kingdom and freedom struggles 200 years back. Therefore they still have the pride and courage to make changes in all aspects of society.

The research also revealed particular community films had influenced the development of the place and individuals of this village in many ways. Almost all the villagers have participated in this film not just to attend but also to make, teach, learn, present, promote, judge, support, and span many artistic disciplines. Most importantly, Quoting to the villagers, some people have given up their lifelong bad habits to become a part of this film. At the end of the film, they have entirely dumped those habits and have started effectively leading their lives. Being a part of this film has added value to their lives, and it has empowered and educated them to become worthy citizens. As we observed, this film has done an attitudinal change for the majority of villagers. These findings led the researcher to conclude the study with a strong opinion on community filmmaking as a powerful driver for social change.

\section{References}

Berrigan, F. J., \& Unesco (Eds.). (1977). Access: Some Western models of community media. Paris: Unesco.

Carpentier, N., \& Scifo, S. (2010). Introduction: Community media's long march. Telematics and Informatics, 27(2), 115-118. https://doi.org/10.1016/j.tele.2009.06.006

Center for policy alternatives. (n.d.). Best practices and potential for improved information flows in media and civil society. 
Community communication. (2015, May 28). Is Community Video different from Participatory Video? Retrieved from http://www.comcomm.org/2015/05/is-communityvideo-different-from.html

Damiani, L. (2015, March 1). Participatory filmmaking. Engaging communities. The backbone of Think Films. Retrieved from Thinkfilms website: http://thinkfilms.com.au/community-development-and-filmmaking-a-perfect-partnership/

Damiani, L. (2017, June 16). Collaborative filmmaking. I love it when everyone gets involved. Retrieved from Thinkfilms website: http://thinkfilms.com.au/collaborative-filmmaking-loveeveryone-gets-involved/

Jayaratne, T., \& Kellapotha, S. (n.d.). THE POLITICAL ECONOMY OF THE ELECTRONIC MEDIA IN SRI LANKA. 82.

Kumar, P. (2017). The Man Who Started His Own Film Industry In Malegaon | Youth Ki Awaaz. Retrieved November 3, 2019, from Www.youthkiawaaz.com website: https://www.youthkiawaaz.com/2017/09/meet-the-superman-of-malegaon/

Malik, S., Chapain, C., \& Comunian, R. (2014). Spotlight on Community Filmmaking A report on Community Filmmaking and Cultural Diversity Research. Retrieved from Brunel University, University of Birmingham and King's College London website: http://www.communityfilmmaking.com/uploads/1/0/9/7/10973203/spotlight_on_community _filmmaking3.pdf

Malik, S., Chapain, C., \& Comunian, R. (2017). Rethinking cultural diversity in the UK film sector: Practices in community filmmaking. Organization, 24(3), 308-329. https://doi.org/10.1177/1350508416689094

McKay, G. (2010). Community Arts and Music, Community Media: Cultural Politics and Policy in Britain since the 1960s. In Understanding Community Media (pp. 41-52). https://doi.org/10.4135/9781452275017.n4

Milne, E.-J., Mitchell, C., \& De Lange, N. (Eds.). (2012). Handbook of participatory video. Lanham: Rowman \& Littlefield Publishers, Inc. 
Orbach, A., Rain, J., \& Contreras, R. (2015). Community filmmaking as research: $(\mathrm{Re})$ considering knowledge production through the camera's lens. Development in Practice, 25(4), 478-489. https://doi.org/10.1080/09614524.2015.1029437

Punchihewa, M. (2018, November 19). Walapane Satana-how was it made? [In-depth interview].

Punchihewa, M., Punchihewa, A., Karunarathna, W. M., Jayantha, W. M. G., Weerasooriya, M. M., Yapa, S., ... Wahikaluwa. (2018, December 22). Film making experience. [In-depth intrview].

Roberts, T., \& Lunch, C. (2015). Participatory Video. In P. H. Ang \& R. Mansell (Eds.), The International Encyclopedia of Digital Communication and Society (pp. 1-6).

https://doi.org/10.1002/9781118767771.wbiedcs148

Samarawickrama, I. (2019, January 27). Nidahas Aragalayata Aluthin Pana dun Walapane Bus Riyadura. Silumina Newspaper, p. 41.

Sega, Ananda, S., \& Chamindalal. (2018, December 23). The Film making experience [Indepth interview].

Shaw, J., \& Robertson, C. (1997). Participatory video: A practical approach to using video creatively in group development work. London; New York: Routledge.

The Budget. (n.d.). Retrieved November 3, 2019, from https://www.visitamishcountry.com/business/255/the-budget

UNESCO. (n.d.). Community Media Sustainability. Retrieved from https://en.unesco.org/themes/community-media-sustainability

\section{Participatory Observation}

October 242018 - First film Screening at the main hall of Sri Sumangala national school, Nildandahinna, Walapane 
November 19, 2018 - At the Special film screening at the Department of Mass Communication, University of Kelaniya.

April 162019 - Film screening for villagers at Pussadewa central college, Batagolla, Walapane. 